but instead will be at the Royal Horticultural Society's Old Hall, Vincent Square, Iondon, S.W.1, on the following dates and times: April 21 (3-8.30 p.m.), April 22 (2-8.30 p.m.) and April 23 (2-7.30 p.m.). One advantage of this change is that the entire exhibition will be housed in one hall. An exhibition luncheon will take place, as in former years, at the Criterion Restaurant, Piccadilly, London, W.1, on April 21, tickets (one guinea each) for this function being restricted to members of the Association and to two per exhibitor. Applications for these tickets and for copies of the exhibition brochure should be made to the General Secretary, Oil and Colour Chemists' Association, Memorial Hall, Farringdon Street, London, E.C.4, from whom all further information can be obtained.

Fourth International Conference on Electrodeposition and Metal Finishing, London

THE Fourth International Conference on Electrodeposition and Metal Finishing will be held in the Holborn Restaurant, 218 High Holborn, London, W.C.1, during April 20-24. The Conference, which is under the ægis of the International Council for Electrodeposition, will be organized by the Institute of Metal Finishing. About two dozen papers will be read, and a session of particular interest will be one at which a panel of American experts will answer questions relating to practice in the United States. An exhibition of techniques and equipment will be held in conjunction with the Conference. Further information can be obtained from the Conference Secretary at the Institute of Metal Finishing, 32 Great Ormond Street, London, W.C.I.

\section{Royal Society Lectures}

THE following arrangements have been made for Royal Society Lectures during 1954: Leeuwenhoek Lecture, by Prof. J. H. Quastel, professor of biochemistry, McGill University, Montreal, and director of the Research Institute, Montreal General Hospital, on "Soil Metabolism" (May 6) ; Croonian Lecture, by Sir Howard Florey, professor of pathology in the University of Oxford, on "Mucins and the Protection of the Body" (May 27); Bakerian Lecture, by Prof. A. R. Todd, professor of chemistry in the University of Cambridge, on "Chemistry of the Nucleotides" (June 17).

\section{The Night Sky in March}

New moon occurs on March 5d. 03h. 11m., U.T., and full moon on March 19d. 12h. 42m. The following conjunctions with the moon take place : March 11d. 13h., Jupiter $3^{\circ}$ S. ; March 23d. 02h., Saturn $8^{\circ}$ N. ; March 26d. 15h., Mars $3^{\circ}$ N. Mercury is in inferior conjunction on March 1, after which it is a morning star but is unfavourably placed for observation during the month. Venus, an evening star, sets at 18h. $10 \mathrm{~m}$., 18h. 55m. and $19 \mathrm{~h} .45 \mathrm{~m}$. on March 1, 15 and 31 , respectively. Most of the illuminated portion of the disk is visible, and the stellar magnitude is $-3 \cdot 4$ throughout the month. Mars, a morning star, rises at $2 \mathrm{~h}$., $1 \mathrm{~h} .40 \mathrm{~m}$. and $1 \mathrm{~h} .15 \mathrm{~m}$. at the beginning, middle and end of the month, respectively, stellar magnitude $0 \cdot 8-0 \cdot 2$. The great change in brightness is due to the decrease by 27 million miles in the planet's distance from the earth. Jupiter is visible throughout the night, setting in the early morning hours at $2 \mathrm{~h} .35 \mathrm{~m}$., $1 \mathrm{~h} .45 \mathrm{~m}$. and $0 \mathrm{~h} .50 \mathrm{~m}$. on March 1,15 and 31 , respectively, stellar magnitude $-1 \cdot 8$. Saturn is an evening star, rising at $23 \mathrm{~h} ., 22 \mathrm{~h}$. and $20 \mathrm{~h}$. $55 \mathrm{~m}$. at the beginning, middle and end of the month, respectively, stellar magnitude $0 \cdot 6-0 \cdot 5$, and is easily identified in the constellation Libra a little north-west of $\alpha$ Libræ. Occultations of stars brighter than magnitude 6 are as follows, observations being as if made at Greenwich : March 11d. $21 \mathrm{~h} .30 \cdot 4 \mathrm{~m}$., 118 Taur. $f(D)$; March 13d. 18h. 37.9m., $\delta$ Gemi. $(D)$; March 13d. 19h. 44.6m., $\delta$ Gemi. $(R)$; March 13d. 23h. $03 \cdot 9 \mathrm{~m}$., 63 Gemi. $(D)$; March 16d. 22h. 41.4 m., 83 B. Leon. $(D)$; March 17d. 1h. 43.3m., $\pi$ Leon. $(D)$. $D$ and $R$ refer to disappearance and reappearance, respectively. Vernal equinox takes place on March 21d. 04h.

\section{Announcements}

THe essay subjects for this year's Endeavour prizes of the British Association for the Advancement of Science will be as follows: the upper atmosphere; heat of the earth; coal as a raw material; water supply; the span of life ; and colour photography. Essays must be sent in by June 1 and must not exceed four thousand words. Competitors must be twenty-five years old or less on June 1 and the prizes will be 50, 25 and 15 guineas respectively, with two special awards of 5 guineas for those less than eighteen. Further information can be obtained from the Assistant Secretary, British Association for the Advancement of Science, Burlington House, Piccadilly, London, W.1.

DR. R. BRAUDE, of the National Institute for Research in Dairying, has been appointed adviser on pig research to the Agricultural Research Council. The post will only occupy part of Dr. Braude's time, leaving him free to continue active research in this field. He will also act as technical secretary to a committee which is being set up by the Council to review and co-ordinate existing research on pigs, and to propose such other work as is thought desirable.

THE Ministry of Agriculture and Fisheries and the Department of Agriculture for Scotland are offering a number of postgraduate scholarships in agricultural economics, husbandry, statistics and agricultural and dairy engineering, for the academic year beginning next October. The closing date for applications is March 15. Further particulars can be obtained from the Secretary, Ministry of Agriculture and Fisheries (Research Branch), 1-4 Cambridge Terrace, Regent's Park, London, N.W.1 (to whom residents in Northern Ireland should also apply), or the Secretary, Department of Agriculture for Scotland, St. Andrew's House, Edinburgh 1.

THE first part of Current Chemical Papers has now been issued by the Chemical Society (No. 1, pp. 44 ; 1954) and contains the titles, with authors' names and references to the original, of publications received during the whole of the previous month. The entries are classified in ten groups and cover the whole field of chemistry. There will be no index to the publication. Further particulars can be obtained from the Chemical Society, Burlington House, London, W.1.

THE final volume of "Thorpe's Dictionary of Applied Chemistry", announced by Messrs. Longmans Green in Nature of February 20 (Advert. Supp. p. ii), as for publication this month, will not be ready until the early summer.

ERratum. In the communication "Pigmentation of the Jellyfish, Pelagia noctiluca" (Nature, January 23, p. 169, par. 7 , lines 8 and 9, for "but no pyrrole reaction on roasting" read "and a pyrrole reaction on roasting". 